\title{
ks. Krzysztof Góźdź
}

Katolicki Uniwersytet Lubelski Jana Pawła II

\section{Logosowy charakter wiary według Josepha Ratzingera - Benedykta XVI ${ }^{1}$}

Jednym z priorytetów Roku Wiary, który uroczyście rozpoczął się w Kościele 11 października 2012 roku, jest wyznawanie naszej wiary. Na takie świadectwo prostej i żywej, ale też i odważnej wiary zdobyła się Meseret Defar, Etiopka, zwyciężczyni biegu na $5 \mathrm{~km}$ podczas tegorocznych igrzysk olimpijskich w Londynie. Gdy dobiegła jako pierwsza do mety wyjęła ukryty pod koszulką obrazek Maryi z dzieciątkiem Jezus i na oczach świata ucałowała go. Komentatorzy telewizyjni zamilkli. Polityczna poprawność nie pozwoliła im chyba dostrzec tego, co czuła złota medalistka! Jakże to wielkie zderzenie wiary i niewiary, świadectwa i strachu, „biblijnej” Etiopii i „nowoczesnej” Polski! Etiopii, która może właśnie w tej dziewczynie pokazała, że głęboki kryzys wiary dotknął tak wielu ludzi cywilizacji euroatlantyckiej, a szczególnie ludzi starej i niestety także nowej Europy. Ta sportsmenka pokazała, że Bóg jest z nią, że Bóg jest w jej życiu, że Bóg jest w jej doczesnym świecie.

Czy stać nas na podobny gest prostej i głębokiej wiary? Co należy czynić, by nie wstydzić się naszej wiary? Kim trzeba być, aby przekonywująco żyć wiarą w Boga Jezusa Chrystusa? Na te i podobne pytania znajduje doskonałą odpowiedź pierwszy sługa Chrystusa na ziemi, który trwa mocno w wierze Piotrowej, wyznającej w Jezusie Chrystusie Syna Bożego i Mesjasza, papież Benedykt XVI. W tej apostolskiej wierze, bę-

Wykład inauguracyjny wygłoszony 16 października 2012 roku w Uniwersytecie Papieskim Jana Pawła II w Krakowie. 
dącej fundamentem i opoką Kościoła, mąż ten jako świadek Chrystusa na ziemi ciągle umacnia świat w przekonaniu, że cel naszej ziemskiej wędrówki od strony Boga jest jeden jedyny: jest nim wieczne bycie w Bogu, uczestniczenie człowieka w życiu Trójjedynego Boga. Tę wieczną Bożą wspólnotę zapewni nam pokorna wiara w Boga objawionego w Jezusie Chrystusie.

Teologia klasyczna rozróżniała: wiarę, którą się wierzy - fides qua creditur oraz wiarę jako zespół prawd objawionych, prawdy wiary, treści nauki - fides quae (lub quod) creditur. Z góry należy powiedzieć, że Ratzingerowe ujęcie wiary (fides qua) charakteryzują trzy zasadnicze aspekty: jest to fenomen osobowy (1), wiąże się z Chrystusem jako Logosem - Słowem i Sensem (2) i jest najwyższą realnością człowieczą w Bogu (3).

Wiara jest zatem konieczna dla człowieka, aby mógł jako osoba transcendować świat materialny, doczesność, przemijanie i siebie samego, by osiągnąć nowe, wieczne życie w Bogu, a przez to starał się już teraz przemienić świat obecny w świat Boży. Dlatego wiara według Ratzingera nie jest żadną ślepą teorią, jakąś przestarzałą ideą ani też jakąś zagmatwaną filozofią, lecz jest „znajdowaniem drogi do mądrości, rozumności, rzeczowości, [tj.] dostrzegania pełnej rzeczywistości". ${ }^{2}$ Taka wiara staje się prawdziwą bramą do komunii z Bogiem, Panem historii i Panem wszechświata. Zatem wiara jest kategorią osobową, a nie reistyczną. Dotyczy relacji osobowych, a nie rzeczowych. Jest żywą relacją między człowiekiem a Bogiem, między osobą człowieka, stworzonego na obraz Boży, a Bogiem w Trójcy Osób. Jest to wreszcie relacja osobowej miłości, gdyż Bóg jest Miłością (1 J 4, 8), która udziela się człowiekowi. „Wiara jest więc decyzją na to, żeby być z Panem, aby z Nim żyć”'. Decyzja ta nie może być jednak ślepa, lecz winna opierać się na Logosie, by w ten sposób być także realną rzeczywistością.

W krótkim wykładzie pójdźmy więc śladem wyznaczonym przez samego Josepha Ratzingera, który określa wiarę jako: mądrość, rozumność i realność.

2 J. Ratzinger, Głosiciele Słowa i słudzy Waszej radości. Teologia i duchowość sakramentu święceń, przekł. M. Górecka, M. Rodkiewicz, Lublin 2012, s. 459 (Opera Omnia 12) [dalej: JROO, t. 12].

Benedykt XVI, list apost. Porta fidei, 10, 3. 


\section{Wiara jako mądrość}

Mądrość wiary to najsłuszniejsze odniesienie świata historii, ludzi i siebie samego, moich wszystkich działań do najwyższego Celu, Sensu, Finału i Pleromy rzeczywistości. Wiara, którą wierzymy (fides qua), nie jest rzeczą, zwykłą funkcją, aktem, czymś przypadkowym dla człowieka lub czymś izolowanym od jego bytu i od stworzenia w ogóle, lecz jest najmocniejszym przylgnięciem całoosobowym człowieka do Chrystusa jako Osoby, jako Logosu, czyli Słowa Bożego, Sensu i Rozumu w rzeczywistości stworzonej - przylgnięciem naszym ,ja”, naszym całym umysłem, intelektem, wolą, uczuciem, czynem, twórczością i wyższą transformacją siebie i całego stworzenia Bożego (por. Rz 8, 18-24). Ratzinger - Benedykt XVI przyjmuje w swej teologii, jak sam mówi, personalizm, zapewne augustyński ${ }^{4}$. I tak ujmuje wszelką rzeczywistość: Boga, człowieka, świat, dzieje, Kościół, zbawienie z punktu osoby jako najwyższego bytu i najgłębszego sensu wszelkiej rzeczywistości. Inaczej mówiąc, Osoby Boże i osoba ludzka - poprzez luźną analogię - są najwyższą i absolutną racją istnienia Boga i człowieka. Stąd wiara to nie tylko jakaś myśl o Bogu, jakąś ufność czy gest ofiarny, ale nowy rodzaj egzystencji człowieka jako osoby w Osobach Bożych - realnie, ponadrealnie, spełnieniowo, pleromicznie. Jest to "wwiązanie” osoby ludzkiej w Osoby Boże (Inpersonlisation) ${ }^{5}$.

Dlatego według Ratzingera - Benedykta XVI popularne, nawet wśród teologów, powiedzenie, że „,wiara jest łaską”, nie oddaje pełnej prawdy o wierze i może być błędnie rozumiane. Zdarza się często, że różni ludzie, najczęściej niewierzący, wygłaszają niby teologiczne teorie, że „nie otrzymali łaski wiary". Tym samym niejako obwiniają samego Pana Boga, że im tej łaski nie dał i dlatego nie wierzą w Niego. W teologii są tu dwa stanowiska ${ }^{6}$ : według jednych „wiara jest tylko łaską", zgodnie z banezjańską koncepcją łaski jako praemotio physica, czyli jakby fizycznej przemocy (co można odnieść najwyżej

4 Por. Joseph Ratzinger Volk und Haus Gottes in Augustinus Lehre von der Kirche, Freiburg im Breisgau 2011 (Gesammelte Schriften 1).

Por. K. Góźdź, Die personalelistische Ergänzung des Chalkedonischen Dogmas, [w:] Mittler und Befreier. Die christologische Dimension der Theologie, hrsg. Ch. Schaller, M. Schulz, R. Voderholzer, Freiburg i. Br. 2008, s. 109.

Por. nowe ujęcie traktatu o łasce hiszpańskiego teologa: J. L. Lorda, Łaska Boża, przeł. J. Lekan, Lublin 2012. 
np. do nawrócenia św. Pawła Apostoła), a według drugich jest możliwa inicjacja wiary naturalnej: fides naturaliter acquisita, którą Bóg jednocześnie wspiera łaską. Otóż według Ratzingera - Benedykta XVI wiara jest misteryjną syntezą: Bóg daje łaskę wiary, daje sam siebie każdemu człowiekowi, i to zawsze, ale człowiek nie jest rzeczą, istotą bezosobową, dlatego narzucenie mu łaski „siłą" byłoby jego poniżeniem; stąd człowiek ma swój udział w zjawisku wiary, może się na nią otworzyć lub nie, może ją przyjąć albo odrzucić, może ją rozżarzać a może ją zamącić - z powodu grzechów lub różnych innych przyczyn. Toteż wiara jest współkomunią osobową dwu lub więcej osób, a przede wszystkim osoby ludzkiej z Osobą Bożą na sposób osobowy, nie reistyczny. I tak wiara ma charakter ontyczny i realistyczny: jest realnym związkiem osobowym bytu ludzkiego z Bytem Bożym. I człowiek może ją dopełnić we współpracy z Chrystusem i Duchem Świętym, żeby stać się Bożym człowiekiem.

Mądrościowy, a zarazem osobowy charakter wiary dostrzegał Ratzinger już w latach 60. XX wieku. Według niego istota chrześcijaństwa wyraża się głównie w tym, że jest ono "wiarą" w Jezusa Chrystusa jako wcielonego Syna Bożego. Wiara ta nie jest jednak „ujrzeniem” czy wręcz „,dotknięciem”, jak to zwykle bywa z osobą czy rzeczą w świecie widzialnym. Do wiary wiedzie inna droga. Jest nią „opowiedzenie się” za tym, czego nie można ani ujrzeć, ani dotknąć. Opowiedzieć się za Jezusem jako Logosem oznacza konkretnie „ujrzeć” tę rzeczywistość jako tę, która „utrzymuje i umożliwia wszelką rzeczywistość", a więc umożliwia także i moją ludzką egzystencję, umożliwia moje bycie człowiekiem, moje bytowanie na sposób ludzki. „Wierzyć znaczy uznać, że wewnątrz egzystencji ludzkiej istnieje punkt, który nie może zasilać się tym, co widoczne i dotykalne, ani na tym się opierać, ale który styka się z tym, czego dojrzeć nie można, tak że staje się to dla niego dotykalne i okazuje się niezbędne dla jego egzystencji." Taką postawę można osiągnąć jedynie przez proces, który Biblia określa jako „odwrócenie”, „nawrócenie”. Człowiek musi się „odwrócić” od tego, co widzialne, aby pójść za tym, co niewidzialne. Musi dokonać tego zwrotu swojej egzystencji.

Mądrość wiary polega więc na dwóch aspektach tego samego aktu: najpierw „stać przy czymś”, a następnie „rozumieć”. Wiara jako „stanie” przy Bogu oznacza trwanie przy Nim. Jest to treść wiary, czyli ufne stanięcie na gruncie słowa Bożego, a więc zajęcie pewnego stanowiska. Natomiast „rozu-

J. Ratzinger, Wprowadzenie w chrześcijaństwo, przekł. Z. Włodkowa, Kraków 1994, s. 43. 
mienie" jest intelektualnym ujęciem wiary, które Septuaginta wyraża w słowach tradycji logosowej: "Jeśli nie uwierzycie, to i nie zrozumiecie”. Mamy tu do czynienia nie tylko z przyjmowaniem wiary od kogoś, ale też jej własnym rozumieniem. Do istoty wiary należy więc zawierzenie komuś, a nie sobie. Zawierzenie Temu, kto jest fundamentem mojego działania ${ }^{8}$. Wierzyć to zaufać Sensowi, który utrzymuje mnie jako człowieka i cały świat. Zatem moje istnienie jest odpowiedzią na Słowo-Logos, które wszystko podtrzymuje. Odpowiedź ta jest zgodą człowieka na sens, który może on jedynie otrzymać, a nie nadać. I dlatego wiara jest przyjęciem i powierzeniem się temu Sensowi ${ }^{9}$. Jest przyjęciem tego, co niewidzialne, przyjęciem tej rzeczywistości, której się człowiek powierza i na której się opiera. Jedynie ta rzeczywistość, która jednocześnie jest osobowa i transcendentna, jedynie ona jest Absolutem i jako taka jest absolutnie osobowa, a przez to jest źródłem i miejscem wszystkiego, co duchowe, ma prawo odbierać pełną cześć naszej wiary ${ }^{10}$.

\section{Wiara jako rozumność}

Łacińskie słowo credo i hebrajskie amen, otwierające i zamykające wyznanie wiary, mają ten sam źródłosłów, oznaczający: stanąć z pełnym zaufaniem na konkretnej podstawie, której nie ja jestem twórcą, lecz Sens świata. Dlatego powierzam się temu Sensowi, a przez to przybliżam się do samej prawdy w nim tkwiącej, która się przede mną coraz bardziej otwiera. Wtedy wiara - rozumiana jako zaufanie, zawierzenie, wierność, stałość, trwanie - oznacza ostateczne oparcie się na tej podstawie, która stanowi dla człowieka sens życia. Podstawą tą jest prawda, która pochodzi od sensu, od logosu. Dlatego wiara nie jest wiedzą o funkcjonalności, którą da się wyliczyć, lecz jest rozumieniem sensu, który się nam powierzył. Stąd wiara musi trwać przy tym sensie, trzymać się go, bo on jest jej oparciem ${ }^{11}$. Zatem „rozumienie wyrasta tylko z wiary. [...] Wiara i rozumienie należą do siebie nie mniej niż wiara i stanie przy czymś, bo stanie przy czymś i ro-

Tamże, s. 60.

Tamże, s. 63.

10 Por. H. de Lubac, Das Apostolische Glaubensbekenntnis, [w:] Credo. Ein theologisches Lesebuch, hrsg. J. Ratzinger, P. Henrici, Köln 1992, s. 15.

${ }_{11}$ J. Ratzinger, Wprowadzenie w chrześcijaństwo, dz. cyt., s. 67. 
zumienie są nierozłączne" ${ }^{12}$. W tym znaczeniu mówimy o misterium, które nie neguje rozumu, lecz umożliwia wiarę jako rozumienie. Ta rozumująca wiara trzyma się logosu, by mówić o Bogu jako tajemnicy, która nas ciągle uprzedza i pod każdym względem przekracza. Wiara ta ostatecznie wyraża się w osobowym wyznaniu: „Wierzę w Ciebie, Jezusa z Nazaretu, jako Sens (Logos) świata i mojego życia"13.

To wyznanie wiary w Jezusa rozbudowuje Joseph Ratzinger, mówiąc: „My natomiast mamy inną miarę wielkości: Syna Bożego, prawdziwego człowieka. To On jest wyznacznikiem prawdziwego humanizmu. Wiara «dorosła» nie idzie z prądem mód i nowinek; wiara dorosła i dojrzała jest głęboko zakorzeniona w przyjaźń z Chrystusem. Ta przyjaźń otwiera nas na każde dobro, dając nam zarazem kryterium rozeznania prawdy i fałszu, odróżnienia ziarna od plew"14. Mocne stanowisko kardynała określa jednoznacznie wiarę chrześcijańską. Posiada ona wymiar racjonalny, „logosowy” oraz egzystencjalny ${ }^{15}$. Następnie dodaje do tego jeszcze wymiar chrystologiczny i eklezjalny, czyli wspólnotowy naszej wiary. „Wiara to głębokie przekonanie, że Bóg przez Chrystusa w Duchu Świętym rzeczywiście jest i działa w Kościele. Wierzyć znaczy być przekonanym, że Bóg jest wystarczająco duży, aby dostrzec także to, co małe, że On rzeczywiście może działać w świecie i że tam działa. Jest to przekonanie o tym, że On, ponieważ istnieje i ponieważ przed Nim znajduje się nasze życie, jest w tym naszym życiu najważniejszy. Dopiero tam, gdzie to przekonanie kształtuje postać życia, tam wiara jest pełna" ${ }^{16}$. Wiara rozświeca umysł, a rozum przyjmuje wiarę za swoją, za osobistą, za własną strukturę i człowiek wierzący jest w pełni rozumny. Przy tym wiara jest przyjmowana przez wolność rozumną i rozum wolny. Wiara jest rozumna dla człowieka, bo jest wolna (certitudo voluntaria), daje mu wolność, a nie niweczy go, nie gwałci ${ }^{17}$.

Tamże, s. 68

13 Tamże, s. 70.

14 J. Ratzinger, Homilia na rozpoczęcie konklawe, z dnia 18 kwietnia 2005, [w:] Benedykt XVI, U progu pontyfikatu, Kraków 2005, s. 43.

15 Por. M. Bartosiak, Wiara według kard. Josepha Ratzingera, Łomża 2005, s. 10, 12.

16 JROO, t. 12, s. 297.

17 Por. J. Ratzinger, Wiara i teologia (Wykład na Papieskim Wydziale Teologicznym we Wrocławiu z okazji nadania godności doktora honorowego), „Wrocławski Przegląd Teologiczny” R. 8, nr 2 (2000), s. 7-13. 
Dzięki rozumności wiara staje się światłem odkrywającym sens naszego życia, który płynie z poznania woli Bożej. „To coś pięknego - pisze Ratzinger - znać Boga i być poznanym przez Niego. To coś pięknego wiedzieć, jak On wygląda: w obliczu Chrystusa, który ukochał każdego z nas z osobna i za nas wydał się na śmierć, widzimy twarz samego Boga"18. Wartość naszej wiary winniśmy postrzegać od wewnątrz, od wypływającej z nas radości, jaka jaśniała na twarzach pierwszych chrześcijan. Dopiero wtedy dostrzeżemy, jak nieocenioną wartość posiada nasza wiara. Dopiero wtedy poznamy, że „ćwiczenie się w wierze jest ćwiczeniem się w prawdziwym człowieczeństwie oraz nauczeniem się rozumu wiary"19.

\section{Wiara jako realność}

Jeśli świat, rzeczywistość są słowem Boga do człowieka, to Chrystus jest Sensem tego słowa i Duch Święty daje realne ujmowanie tego Sensu, a człowiek jako słowo stworzone może osiągnąć ten Sens - Logos Boży. Potrzebna jest mu do tego wiara, by spotkał Chrystusa, najpełniejszego świadka Boga Ojca, który przez swoje odwieczne zjednoczenie z Nim i „dzielenie” z nami Człowieczeństwa (Człowieczeństwo Boga) - jest obecnością Wiecznego na tym świecie. Dzięki temu wieczne staje się historyczne, niedotykalne daje się dotknąć, dalekie staje się bliskie, po prostu moje. W życiu Chrystusa, „w Jego bezwzględnym oddaniu swego istnienia ludziom mieści się sens świata: On nam oddaje się jako miłość, która także i mnie kocha i przez ten niepojęty dar trwałej miłości, której nie grozi żadna przemijalność, żadne zakłócenie egoizmem, czyni życie wartym życia"20.

Wiara chrześcijańska ma zatem swoją realność poprzez to, że jest wiarą trynitarną: wiarą w Ojca, w Logos i Pneumę ${ }^{21}$, uformowaną w tradycji apostolskiej i powiązaną z jednym podmiotem, którym jest Kościół ${ }^{22}$. Wiara ta bazuje na fundamencie świętych wydarzeń Wcielenia, Krzyża

18 JROO, t. 12, s. 325.

19 Tamże, s. 48.

20 J. Ratzinger, Wprowadzenie w chrześcijaństwo, dz. cyt., s. 69.

${ }_{21}$ Tenże, Teologia liturgii. Sakramentalne podstawy życia chrześcijańskiego, przeł. W. Szymona, Lublin 2012, s. 125 (Opera Omnia 11) [dalej: JROO, t. 11].

22 Tamże, s. 134. 
i Zmartwychwstania, ${ }^{23}$ rodzi się ze słuchania słowa Bożego, ${ }^{24}$ realizuje się w kulcie i liturgii Kościoła, ukierunkowana jest na Logos, stwórczy Rozum, który w Jezusie Chrystusie przyjął ciało ${ }^{25}$. Dlatego wiara ta, będąc wiarą we Wcielonego, jest wyznaniem wiary w Boga i staje się rzeczywista, pełna i jednocząca, gdy „On sam jest ciałem, gdy jest wydarzeniem sakramentalnym, w którym cielesny Pan przyjmuje naszą cielesną egzystencję $e^{26}$. Przez tę ofiarę eucharystyczną dokonuje się głębokie przeobrażenie naszego bytu w Logosie i zjednoczenie z Nim. Tak kult sprawia, że sami upodabniamy się do Logosu ${ }^{27}$, realizujemy się na kształt Logosu i przez wiarę stajemy się Logosem - „oto ofiara i rzeczywista chwała Boża w świecie!”"28.

I choć dzisiaj świat zapomina o boskich wartościach, jak prawda, miłość, sprawiedliwość, a wśród nich nie tylko zapomina wiarę, a wręcz ją neguje, kontestuje i stara się ją uczynić bezsilną, to jednak wiara nie jest bezsilna, gdyż nie jest czymś wymyślonym przez człowieka ${ }^{29}$, nie jest produktem wspólnoty, lecz pochodzi „z góry”, od Boga, od Ducha Świętego i zawsze jest gromadzeniem, jednoczeniem, łączeniem tego, co zostało rozproszone ${ }^{30}$. Boży Duch zespala nas we wspólnym wyznawaniu wiary, która jest wiarą Kościoła, a jego teologia jest wykładnią wspólnej wiary i jej miarą ${ }^{31}$.

Trzeba zatem mieć pokorę i odwagę, a nade wszystko głęboką wiarę, by pośród wielkiego obumierania naszej wiary wokół nas, czy wręcz negacji wiary czy też negacji Boga, być transparentnym dla miłości Chrystusa w naszym życiu. Chodzi o doświadczenie wiary jako prawa akceptacji, jako zaproszenia do wspólnej radości. Wiara chrześcijańska nie jest bowiem zaciętą niekończącą się dyskusją czy wiecznym kwestionowaniem. „Wiara w samej głębi jest akceptacją. Ona jest «tak». Ona jest radością. I pochodzi od Bożego «tak» w nas i dla nas" ${ }^{32}$. Wtedy wiara rzeczywiście staje się nośną siłą człowieka, staje się po prostu miłością.

\footnotetext{
23 Tamże, s. 92.

24 Tamże, s. 524.

25 Tamże, s. 644.

26 Tamże, s. 324.

27 Tamże, s. 615.

28 Tamże, s. 50.

29 JROO, t. 12, s. 41.

30 Tamże, s. 515.

31 Tamże, s. 516.

32 Tamże, s. 606.
} 
Wiara jest zatem specyficznym miejscem pojednania: „Wszystko rodzi się z wiary. Świat jest piękny, bo Bóg stał się człowiekiem i zamieszkał między nami, wraz z nami cierpi i żyje. Żyjąc tą radością, możemy ją nieść także innym, odrzucając zło jako «słudzy pokoju i pojednania»" ${ }^{33}$. Dzięki temu pojednaniu spełnia się warunek samej wiary: ona prowadzi do realnej rzeczywistości zjednoczenia osoby ludzkiej z Osobami Bożymi, do naszego przebóstwienia, do naszego wejścia w obręb życia Trójjedynego Boga. Droga ku wiecznemu życiu człowieka prowadzi przez mądrość, rozumność i jest jak najbardziej realna.

Cóż zatem powinien robić człowiek wierzący w Boga objawionego w Chrystusie? Zdaniem Josepha Ratzingera ma on budzić wiarę wśród ludzi, by wyswobodzić ich z ospałości i zwątpienia, by dawać im „odwagę postrzegania Boga jako rzeczywistość w tym świecie i w życiu. Tylko wtedy, gdy tak się dzieje, świat może żyć i trwać" ${ }^{34}$. Czy zatem owa etiopska biegaczka z igrzysk olimpijskich w Londynie nie dodała nam odwagi w wyznawaniu naszej wiary? Czy jej pokorne świadectwo nie dało nam pewności, by w dzisiejszym świecie głosić Chrystusa, który jest w nim żywą Obecnością? Może właśnie dzięki tej etiopskiej dziewczynie potrafimy zrozumieć i przyjąć jedną z podstawowych tez chrześcijaństwa, że Bóg nie jest gdzieś zamknięty w niebie, w innym i dalekim od nas świecie, lecz że On jest tu z nami, z każdym człowiekiem. Inaczej prawda o Wcieleniu Słowa Bożego byłaby zwykłym fałszem, a tak nie jest! Bóg jest z nami i pośród nas. Inaczej nasza wiara i religia byłyby bezsensowne!

Wiara w Boga Wcielonego, Ukrzyżowanego, Zmartwychwstałego i Uwielbionego w Jego Synu - ma ostatecznie prowadzić człowieka do odkrywania pełnej rzeczywistości Stwórcy i osobowego stworzenia, pełnej - bo z Bogiem Wcielonym, a nie bez Niego. Wtedy ten Wcielony Bóg da nam odwagę trzeźwości Jana Chrzciciela, czyli taką siłę, by dzięki spojrzeniu w naszym życiu doczesnym na naszego Boga trwać niewzruszenie w cierpliwości rozumu! Rozum bowiem nie z pozycji filozofii Boga, lecz z pozycji żywej, rzeczywistej relacji z Osobą Jezus Chrystusa - nakazuje

33 Benedykt XVI, Castel Gandolfo (5 VIII 12).

34 JROO, t. 12, s. 458. 
w zaufaniu do tej Osoby Pana budować nasze własne życie, może tak jak ta Etiopka na olimpiadzie. Dopiero wtedy dojdziemy do dostrzeżenia pełnej rzeczywistości zarówno Boga, jak i człowieka.

Ratzinger ma zatem wielki zmysł filozoficzny. Unika fideizmu, subiektywizmu, irracjonalizmu w pojmowaniu wiary. Widzi ją jako najwyższą egzystencję umysłu, rozumu, woli, miłości i realizacji człowieka w Trójcy Świętej. I tak Benedykt XVI jest wielkim Umocnicielem wiary dla nas, dla „braci w wierze” (Łk 22,32). W zasadzie cały jego pontyfikat jest wielką obroną Bóstwa Jezusa Chrystusa wobec relatywizmu i sekularyzmu świata Zachodu.

\section{The Logos-based nature of faith according to Joseph Ratzinger - Benedict XVI}

According to Ratzinger, faith is not a blind theory or an outdated concept. Neither is it an intricate philosophical system. Instead, he defines faith as "finding a way towards wisdom, rationality and factuality; [that is] a way towards perceiving reality in full." This kind of faith becomes a gate to the communion with God, Lord of history and Lord of the universe. Thus, faith is a personal and not a material category. It belongs to the world of personal and not material relations. "Faith is a decision to be with Lord, and to live with Him." Nevertheless, the decision cannot be a blind choice. It must rest on Logos, so that it truly is a fact-based reality. Claiming that, Ratzinger discloses his great philosophical mind. He skilfully avoids fideism, subjectivism or irrationalism in comprehending faith. He can see faith as the highest level of existence of the mind, reason, will, love and man self-fulfilment in the Holy Trinity.

Keywords: Jesus Christ, Logos, person, faith, Christ's Church, Joseph Ratzinger

Słowa kluczowe: Jezus Chrystus, Logos, osoba, wiara, Kościół Chrystusowy, Joseph Ratzinger 